\title{
Diurnal and Seasonal Variations of Meteorology and Aerosol Concentrations in the Foothills of the Nepal Himalayas (Nagarkot -1,900 m asl)
}

DOI:

10.1007/s13143-016-0002-3

\section{Document Version}

Final published version

Link to publication record in Manchester Research Explorer

Citation for published version (APA):

Shrestha, R., Gallagher, M., \& Connolly, P. (2016). Diurnal and Seasonal Variations of Meteorology and Aerosol Concentrations in the Foothills of the Nepal Himalayas (Nagarkot $-1,900 \mathrm{~m}$ asl). Asia-Pacific Journal of

Atmospheric Sciences, 52(1), 63-75. https://doi.org/10.1007/s13143-016-0002-3

Published in:

Asia-Pacific Journal of Atmospheric Sciences

\section{Citing this paper}

Please note that where the full-text provided on Manchester Research Explorer is the Author Accepted Manuscript or Proof version this may differ from the final Published version. If citing, it is advised that you check and use the publisher's definitive version.

\section{General rights}

Copyright and moral rights for the publications made accessible in the Research Explorer are retained by the authors and/or other copyright owners and it is a condition of accessing publications that users recognise and abide by the legal requirements associated with these rights.

\section{Takedown policy}

If you believe that this document breaches copyright please refer to the University of Manchester's Takedown Procedures [http://man.ac.uk/04Y6Bo] or contact uml.scholarlycommunications@manchester.ac.uk providing relevant details, so we can investigate your claim.

\section{OPEN ACCESS}




\title{
Diurnal and Seasonal Variations of Meteorology and Aerosol Concentrations in the Foothills of the Nepal Himalayas (Nagarkot: $1,900 \mathrm{~m}$ asl)
}

\author{
Rudra K. Shrestha ${ }^{1,2}$, Martin W. Gallagher ${ }^{1}$, and Paul J. Connolly ${ }^{1}$ \\ ${ }^{1}$ Centre for Atmospheric Science, School of Earth, Atmospheric and Environmental Sciences, The University of Manchester, Manchester, UK \\ ${ }^{2}$ Sustainable Consumption Institute (SCI), The University of Manchester, Manchester, UK
}

(Manuscript received 2 June 2015; accepted 11 February 2016)

(C) The Korean Meteorological Society and Springer 2016

\begin{abstract}
A 10-months long monitoring experiment to investigate the diurnal and seasonal variation of aerosol size distribution at Nagarkot (1,900 m asl) in the Kathmadu Valley was carried out as part of a study on katabatic and anabatic influence on pollution dispersion mechanisms. Seasonal means show total aerosol number concentration was highest during post-monsoon season $(775 \pm 417$ $\mathrm{cm}^{-3}$ ) followed by pre-monsoon $\left(644 \pm 429 \mathrm{~cm}^{-3}\right)$ and monsoon $\left(293 \pm 205 \mathrm{~cm}^{-3}\right)$ periods. Fine particle concentration $\left(0.25 \mu \mathrm{m} \leq \mathrm{D}_{\mathrm{P}}\right.$ $\leq 2.5 \mu \mathrm{m}$ ) dominated in all seasons, however, contribution by coarse particles $\left(3.0 \mu \mathrm{m} \leq \mathrm{D}_{\mathrm{P}} \leq 10.0 \mu \mathrm{m}\right)$ is more significant in the monsoon season with contributions from particles larger than $10.0 \mu \mathrm{m}$ being negligible. Our results show a regular diurnal pattern of aerosol concentration in the valley with a morning and an evening peak. The daily twin peaks are attributed to calm conditions followed by transitional growth and break down of the valley boundary layer below. The peaks are generally associated with enhancement of the coarse particle fraction. The evening peak is generally higher than the morning peak, and is caused by fresh evening pollution from the valley associated with increased local activities coupled with recirculation of these trapped pollutants. Relatively clean air masses from neighbouring valleys contribute to the smaller morning peak. Gap flows through the western passes of the Kathmandu Valley, which sweep away the valley pollutants towards the eastern passes modulated by the mountain - valley wind system, are mainly responsible for the dominant pollutant circulation patterns exhibited within the valley.
\end{abstract}

Key words: Himalayas, aerosol, Kathmandu Valley, mountain-valley circulation

\section{Introduction}

Urban air pollution is a major concern in the developing world due to its potential effects on air quality, human health and consequences for regional climate change (Akimoto, 2003; Kan and Chen, 2004; Liao et al., 2015). Such effects are becoming increasingly pronounced in the rapidly developing region of Nepal (Hindman and Upadhayay, 2002; Panday and Prinn, 2009; Gurung and Bell, 2013), and in particular the Kathmandu Valley where population growth and urbanization

Corresponding Author: Rudra Shrestha, Canadian Centre for Climate Modelling and Analysis, Environment and Climate Change Canada, University of Victoria, Victoria, BC, V8W 2Y2, Canada.

E-mail: rudrastha@gmail.com has shown dramatic rises (Thapa and Murayama, 2011). There is limited published literature available on air pollution characteristics within the Kathmandu Valley, but it will be useful to briefly review this in context with current concerns.

The mountain - valley wind system and monsoon rainfall are considered as major drivers in controlling pollutant circulation and dispersion in the Himalayan region (Nakajima, 1976; Shrestha et al., 2000; Shrestha et al., 2002; Shrestha et al., 2010; Panday and Prinn, 2009). In mountain - valley terrain, daytime anabatic winds generally transport pollutants within the valley to higher altitude whilst katabatic winds re-circulate them during the night. This mechanism has been well documented in the Sierra-Nevada Mountains and Great Basin, in the USA (Kim and Stockwell, 2007) and also in the Lower Fraser Valley of British Columbia, Canada (Martilli and Steyn, 2004). Furthermore, scavenging of aerosol particles by rainfall could play a significant role in washing out pollutants (Radke et al., 1980; Saha and Moorthy, 2004; Min et al., 2005; Guo et al., 2015). Similar processes can be expected in the Kathmandu Valley which the study here is a part of. A number of studies have highlighted the role of complex topography and associated circulation patterns in the transport of aerosols in mountainous terrain (Beniston, 1987; Whiteman, 2000; Gautam et al., 2011; Grigoras et al., 2012) since aerosol dispersion in such regions is significantly different compared to others (Reid, 1978). In complex terrain, pollutants can often be trapped within a valley (Segal et al., 1988; Brulfert et al., 2006) for sustained periods, localising their properties and impacts and these may be particularly acute in the Nepalese Himalayas (Shrestha et al., 2010), however, explicit understanding requires more in situ observations.

Effective monitoring of atmospheric aerosols and meteorology at mid and high altitude locations in topographically complex regions such as Nepal provides insight into potential climate impact responses to air pollution and important hydrological feedbacks. Since local topographic variation can often result in locally unique circulation patterns (Miao et al., 2015) and interplay between pollutant emissions and transport, long term monitoring is required. This is particularly true of the Kathmandu Valley where, due to the extremely large altitudinal variation, general theory and findings from elsewhere may not be fully transferrable (Panday, 2006). Hence, in 
this paper we aim to provide initial information and insight on the seasonal and diurnal characteristics of aerosol number concentration and size distribution in the mid-hill region of Nepal.

Previous aerosol measurements in Nepal have focused on the high altitude regions where local anthropogenic aerosol emissions are almost negligible due to low population density. These experiments have focused on chemical composition and mass concentration. However, aerosol number and size distribution, an important parameter, e.g. to model aerosol - cloud precipitation interactions, is poorly documented. A short-term (two months) study of surface meteorology and total particle concentration (using a condensation nucleus counter, $\mathrm{CN}$ ) across the Himalayas demonstrated a semi-diurnal variation of particle number concentration with morning and evening maxima and afternoon minima which was consistent with stable air conditions and strong day time convection (Hindman and Upadhayay, 2002).

High concentrations of ultrafine particles $\left(10<\mathrm{D}_{\mathrm{p}}<700 \mathrm{~nm}\right)$ have been observed in the high Himalaya region of Nepal (5079 $\mathrm{m}$ asl) during a 16-month observation of aerosol at the Nepal Climate Observatory Pyramid (Venzac et al., 2008). A maximum diurnal particle concentration was found during the late evening ( 2200 LST) with the pre-monsoon period being the most polluted season. A further two years of observations of aerosol concentration $(10 \mathrm{~nm}-10 \mu \mathrm{m})$ at the same location (Sellegri et al., 2010) confirmed this seasonal variation as did a satellite remote sensing analysis (Shrestha and Barros, 2010). Daily twin peaks of total $\mathrm{PM}_{10}$ and black carbon, one in the morning and the other in the evening were also observed in the Kathmandu Valley (Panday and Prinn, 2009; Putero et al., 2015). In this study we will add to these observations focusing on number concentration and size distribution of aerosol observed at mid-hill altitude range which contributes to our understanding of altitudinal variation and transport of aerosol concentration across the Himalayas.

In section 2 we will describe the general characteristics and meteorology of the Kathmandu Valley in a longer climatological context, while details of the site and experimental set up are discussed in section 3. Section 4 summarizes the analyses and results followed by discussion and conclusion in section 5 .

\section{The Kathmandu Valley: general characteristics and climatology}

The Kathmandu Valley, dominated by the three major cities of Nepal - Bhaktapur, Lalitpur, and the capital Kathmandu, is a bowl-shaped former lake. It has a surface area of approximately $350 \mathrm{~km}^{2}$ with an average altitude of $1,300 \mathrm{~m}$ asl, and is surrounded by a mountain range with altitudes ranging from 2,000-2,800 $\mathrm{m}$ asl. Recent census estimates the population to be more than 2 million and rising. As the valley is surrounded by the other smaller lower valleys (Fig. 1) and hills and passes (Fig. 2) that act as entrances and exits for pollutants, this results in complex circulation patterns. In general, the valley

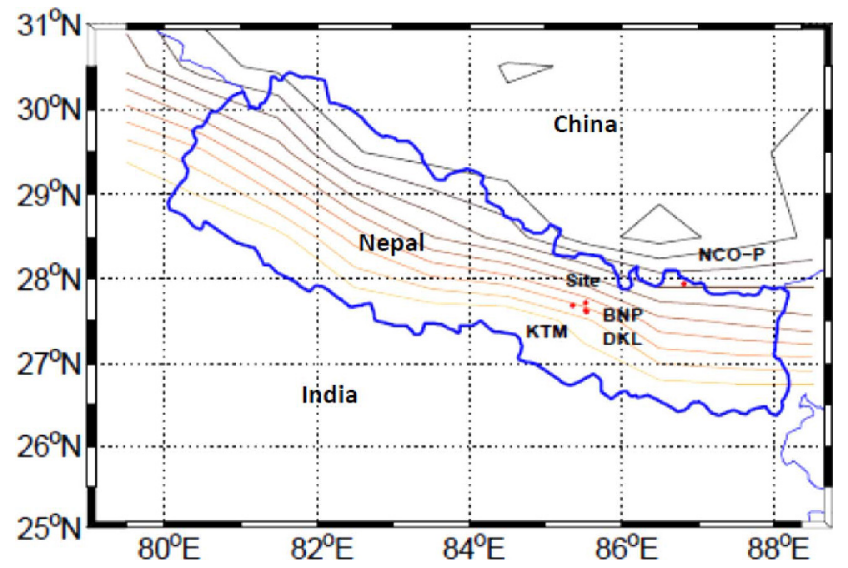

Fig. 1. Location of the measurement site (Nagarkot, Lat: $27.7^{\circ} \mathrm{N}$, Lon: $85.5^{\circ} \mathrm{E}$, Alt: $1,900 \mathrm{~m}$ asl) in the eastern flank of the Kathmandu Valley (KTM). The NCO-P is the Nepal climate observatory pyramid $(5,079 \mathrm{~m}$ asl $)$ situated near the base of Mt. Everest. Dhulikhel (DKL) and Banepa (BNP) are the small valleys in the east of KTM. Elevation contours are plotted at intervals of $500 \mathrm{~m}$ between 1,000-6,000 $\mathrm{m}$ altitudes.

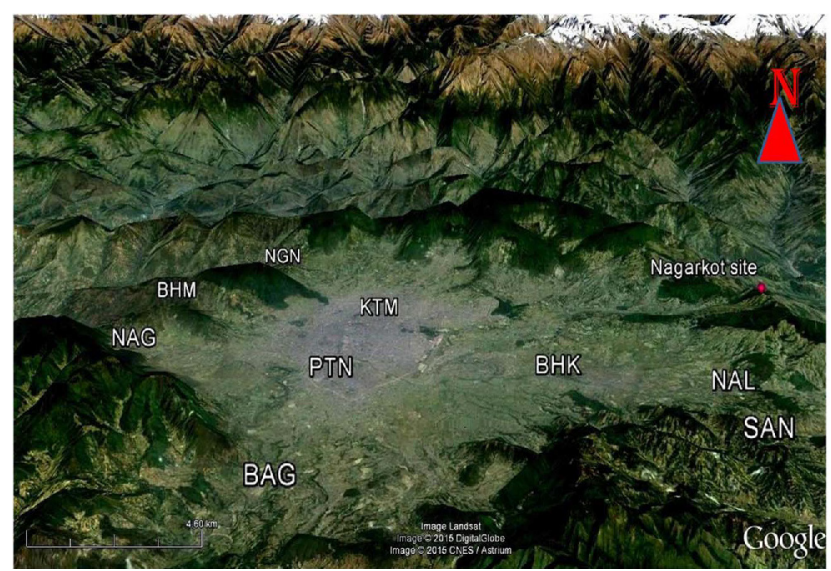

Fig. 2. Google Earth image of the Kathmandu Valley viewed from the south showing the main peaks and passes. Nagarkot peak is the location of the measurement site $(1,900 \mathrm{~m})$. The acronym KTM, PTN and BHK refer to the three major cities, Kathmandu, Patan and Bhaktapur, respectively, in the valley. The Nagdhunga (NAG; 1,480 $\mathrm{m})$ and Bhimdhunga (BHM; 1,500 m) passes are located in the western edge of the valley. The Nala (NAL; $1,530 \mathrm{~m}$ ) and Sanga (SAN; $1,530 \mathrm{~m}$ ) are the eastern mountain passes. The Bagmati river gorge (BAG) and Nagarjun peak (NGN; $2,100 \mathrm{~m}$ ) are located in the south-west and north-west of the valley, respectively.

acts as a plateau pulling in air masses during the day time and as a basin during night time, forming a very deep cold pool (Panday, 2006).

Transport infrastructure in Kathmandu is dominated by fossil fuel powered vehicles, whose numbers have increased significantly over the last decade (ADB/ICIMOD, 2006). Transportation is the largest contributor of local air pollution followed by household emissions, brick kiln factories (Panday and Prinn, 2009) and open garbage burning (Putero et al., 
2015). Household emissions are attributed to home energy sources, typically for cooking two large meals per day, one in the morning and one in the evening, using mainly liquefied petroleum (LP) gas, kerosene and firewood with a small amount of hydro-electricity as the energy sources.

The Kathmandu Valley generally experiences less pollution with greater visibility during the monsoon season (JuneSeptember) as a result of scavenging of pollutants, consistent with the Indian summer monsoon rain that is responsible for more than $80 \%$ of annual rainfall in the valley (Shrestha, 2000). South-westerly warm and moist air originating from the Bay of Bengal encounters the complex terrain of the Himalayas triggering this summer monsoon rainfall, however, significant spatial variation in rainfall is observed within the valley.

During the pre-monsoon season (March-May) strong atmospheric circulation, accompanied with violent thunderstorms due to intense surface heating and associated convection, brings dust laden air from neighbouring deserts (e.g. from India and Pakistan and intercontinental dust from the Sahara desert (Carrico et al., 2003)) to the region. In the winter season (December-February) the valley is relatively cool, dry and dusty, commonly covered by haze with poor visibility. During night time the valley remains calm with clear skies accompanied by a strong temperature inversion that both traps pollutants at the valley floor and triggers dense fog which persists until 0900 or 1000 LST in the morning. Winter precipitation brings light rain over the valley while snowfall in the surrounding hills and mountains is caused by both the winter monsoon and the extra-tropical cyclone locally known as the western disturbance. The valley receives on average approximately $1500 \mathrm{~mm} \mathrm{yr}^{-1}$ of rain. Annual temperatures are $\sim 18^{\circ} \mathrm{C}$ (Alford, 1992; Shrestha et al., 1999) with a maximum of $\sim 35^{\circ} \mathrm{C}$ during the month of May and below freezing during January mornings.

\section{Experimental setup}

The measurement site - Nagarkot is located on the eastern flank of the Kathmandu Valley (Lat: $27.7^{\circ} \mathrm{N}$, Lon: $85.5^{\circ} \mathrm{E}$ ). The altitude of the measurement site is about $1,900 \mathrm{~m}$ asl and is located in the so-called "middle hill" region of Nepal, approximately half-way between the Indo-Gangetic plain and the Tibetan plateau. At this site a small monitoring station consisting of an optical particle counter (OPC) (GRIMM Model 1.109) with a PM-10 inlet, and a Vaisala meteorological sensor (Met Pack WTX 510) were installed on the roof top of a two story public health office building. The station was located approximately $5 \mathrm{~m}$ above the ground. The station was mounted on a mast above the corner of the rooftop parapet offering good $360^{\circ}$ exposure. Data was recorded to a notebook computer for the period March to December 2011.

Aerosol particle concentrations in 31 different size channels ranging from $0.25 \mu \mathrm{m}$ to $32 \mu \mathrm{m}$ were measured by the GRIMM OPC via a light scattering technique to measure and count individual particles. Air is drawn in to the OPC via a flow- controlled pump at a rate of $1.21 \mathrm{~min}^{-1}$. This is then passed through a laser beam where the particle scattering signal is classified using a pulse height analyzer and stored in appropriate size channels. Particle size distributions were recorded at $1 \mathrm{~Hz}$ and averaged over $1 \mathrm{~min}$. In addition, the OPC station provided additional measurements of ambient relative humidity and temperature again with a temporal resolution of $1 \mathrm{~min}$.

The weather station provided measurements of temperature, relative humidity, surface pressure, wind speed (using an ultrasonic anemometer), wind direction, and a precipitation sensor. The precipitation sensor discriminated rainfall and hail using a piezoelectric sensor which measures electrical charge induced from pressure exerted by individual drops and is proportional to the volume of the drops. As with the OPC the meteorological station was set to record variables at $1 \mathrm{~min}$ intervals. Data presented here will be based on hourly averaged values calculated from $1 \mathrm{~min}$ averaged data measured by the $\mathrm{OPC}$ and Vaisala weather sensor.

\section{Results}

\section{a. Local meteorology}

(1) Seasonal variation

Figures 3 and 4 show the time series analysis of meteorological variables measured from March through December 2011. A statistical summary is provided in Table 1. Pressures are at the local altitude to record variation, and are not corrected to sea level.

Pre-monsoon season winds were generally strongest as shown in Fig. 3a and Fig. 5. Maximum gusts occurred in April and reached around $9 \mathrm{~m} \mathrm{~s}^{-1}$. These high gust periods can be attributed to the strong thermal circulation in the valley associated with high daytime surface temperatures followed by strong night time cooling. In general the prevailing wind direction was from southwest to west (Fig. 7a). Very little rainfall was recorded in the beginning of the pre-monsoon season and any events were of low intensity however, towards the end of the season rainfall intensity increased significantly reaching as high as $34 \mathrm{~mm} \mathrm{~h}^{-1}$ (Fig. 3b). Nine hail days were recorded in this season which is a general feature of the region prior to onset of the monsoon. The maximum amount $(79 \mathrm{~mm})$ of hail was recorded in the late afternoon of 10 May 2011. Atmospheric pressures fluctuated between $801 \mathrm{hPa}$ to $815 \mathrm{hPa}$ and surface temperatures generally increased over time (Fig. 4b) with maximum reported temperatures in March of $19.2^{\circ} \mathrm{C}$ increasing to $25.4^{\circ} \mathrm{C}$ by the end of May. Similarly relative humidity $(\mathrm{RH})$ was highly variable in the beginning of the season but on average increased significantly towards the end of the season (Fig. 4c) indicative of the arrival of the monsoon season.

In the monsoon season winds decreased in strength, with mean speeds of $1.9 \mathrm{~m} \mathrm{~s}^{-1}$. The wind came from all directions particularly in middle of the season. However, NE and SW 
(a)

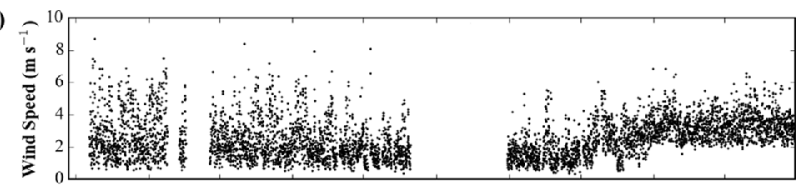

(b)

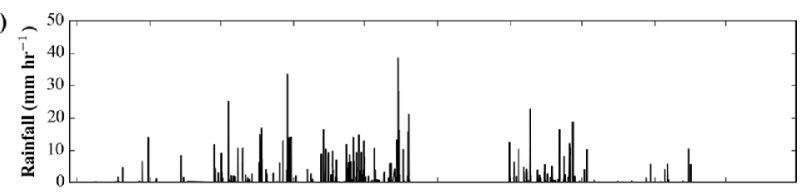

(c)

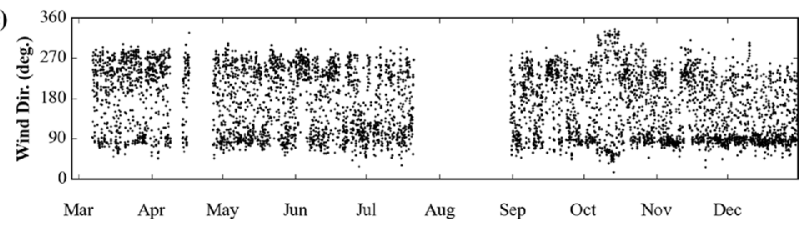

Fig. 3. Time series analysis of meteorological variables (hourly average data) showing (a) wind speed $\left(\mathrm{m} \mathrm{s}^{-1}\right)$, (b) rainfall $\left(\mathrm{mm} \mathrm{hr}^{-1}\right)$, and (c) wind direction (deg). The measurement gap is due to power outages.

winds were dominant throughout this season. Rainfall was generally mild but continuous (Fig. 3b), again a typical characteristic of the Indian monsoon, with no hail events were recorded. Atmospheric pressure was lower than the other seasons with a seasonal mean pressure of $805.7 \mathrm{hPa}$. Temperature also displayed a stable trend throughout the season with maxima close to $25^{\circ} \mathrm{C}$, similar to the pre-monsoon season. In general RH remained high throughout the season, generally above $80 \%$.

In the post-monsoon season $\mathrm{SW}$ winds became established. Mean wind speeds were $2.9 \mathrm{~m} \mathrm{~s}^{-1}$ with maximum gusts of $15.9 \mathrm{~m} \mathrm{~s}^{-1}$. Several episodes of low intensity rain and hail were also recorded. A sudden rise in the pressure was observed in the beginning of the season which remained stable over the entire season. The highest recorded pressure $(817 \mathrm{hPa})$ over the year was reported during this period. Temperature showed a decreasing trend over time with maximum values around

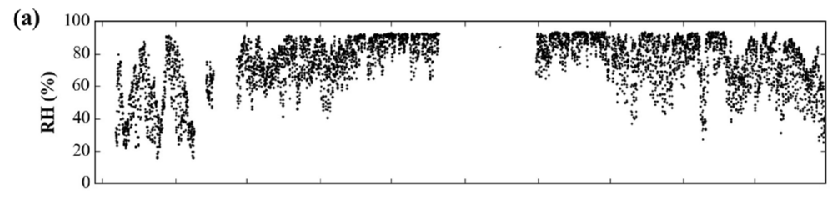

(b)
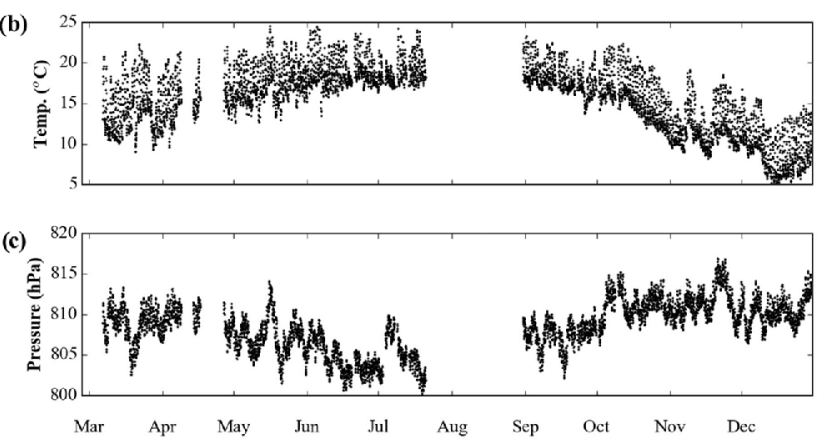

Fig. 4. Same as Fig. 3 but for a) relative Humidity (\%), b) surface temperature $\left({ }^{\circ} \mathrm{C}\right)$, and c) atmospheric pressure $(\mathrm{hPa})$, local altitude value.

$22^{\circ} \mathrm{C}$ at the beginning of the season, however, this dropped to almost $8^{\circ} \mathrm{C}$ by the end of November. The $\mathrm{RH}$ decreased compared to the monsoon season with the most pronounced decrease, $\sim 20 \%$, occurring towards the end of the season.

In the winter season NE winds (Fig. 7b), with mean speeds of $3.4 \mathrm{~m} \mathrm{~s}^{-1}$, were dominant, with the strongest winds observed over the year. No rainfall was recorded during this season. Atmospheric pressure dropped relative to the post-monsoon season, fluctuating between 806.0 and $815.5 \mathrm{hPa}$. Surface temperatures dropped steadily from the post-monsoon values. $\mathrm{RH}$ levels generally decreased during the season, dropping by as much as $14 \%$ on average.

\section{(2) Diurnal variation}

Figures 5 and 6 show the diurnal cycles of the mid-hill wind patterns during the different seasons. We observe distinct seasonal diurnal patterns at this location.

In the pre-monsoon season daily twin peaks in wind speed

Table 1. Statistics of meteorological variables at Nagarkot, Nepal.

\begin{tabular}{|c|c|c|c|c|c|c|c|c|c|c|c|c|c|c|c|c|c|c|c|c|}
\hline \multirow{2}{*}{$\begin{array}{c}\text { Meteorological } \\
\text { parameters }\end{array}$} & \multicolumn{5}{|c|}{$\begin{array}{l}\text { Pre-monsoon } \\
\text { (March-May) }\end{array}$} & \multicolumn{5}{|c|}{$\begin{array}{c}\text { Monsoon } \\
\text { (June-September) }\end{array}$} & \multicolumn{5}{|c|}{$\begin{array}{c}\text { Post-Monsoon } \\
\text { (October-November) }\end{array}$} & \multicolumn{5}{|c|}{$\begin{array}{c}\text { Winter } \\
\text { (December-February) }\end{array}$} \\
\hline & Mean & Min & Max & Median & $1 \sigma$ & Mean & Min & Max & Median & $1 \sigma$ & Mean & Min & Max & Median & $1 \sigma$ & Mean & Min & Max & Median & $1 \sigma$ \\
\hline $\begin{array}{c}\text { Relative } \\
\text { Humidity (\%) }\end{array}$ & 62.8 & 12.2 & 91.3 & 66.0 & 18.5 & 84.1 & 35.4 & 93.2 & 87.0 & 9.4 & 76.3 & 20.8 & 93.2 & 79.3 & 13.7 & 67.1 & 14.6 & 93.2 & 68.6 & 15.9 \\
\hline Temperature $\left({ }^{\circ} \mathrm{C}\right)$ & 16.0 & 6.6 & 25.4 & 16.0 & 2.9 & 18.6 & 13.2 & 24.9 & 18.2 & 1.8 & 14.0 & 8.1 & 22.7 & 13.7 & 3.2 & 9.4 & 4.0 & 17.3 & 9.3 & 2.6 \\
\hline $\begin{array}{l}\text { Atmospheric } \\
\text { Pressure (hPa) }\end{array}$ & 808.4 & 801.3 & 815.4 & 808.5 & 2.3 & 805.7 & 799.7 & 7811.0 & 805.8 & 2.3 & 811.3 & 805.9 & 817.0 & 811.2 & 1.9 & 810.5 & 806.3 & 815.6 & 810.4 & 1.8 \\
\hline $\begin{array}{l}\text { Wind Speed } \\
\qquad\left(\mathrm{m} \mathrm{s}^{-1}\right)\end{array}$ & 2.6 & 0.1 & 16.3 & 2.3 & 1.6 & 1.9 & 0.1 & 17.2 & 1.7 & 1.2 & 2.9 & 0.1 & 10.8 & 2.8 & 1.2 & 3.4 & 0.5 & 9.3 & 3.2 & 1.2 \\
\hline $\begin{array}{c}\text { Mean Wind } \\
\text { Direction (sector) }\end{array}$ & \multicolumn{5}{|c|}{ South-West } & \multicolumn{5}{|c|}{ South-East } & \multicolumn{5}{|c|}{ South-East } & \multicolumn{5}{|c|}{ North-East } \\
\hline Rainfall $\left(\mathrm{mm} \mathrm{h}^{-1}\right)$ & 2.8 & 0.0 & 33.6 & 0.0 & 2.8 & 5.6 & 0.0 & 42.5 & 0.0 & 3.6 & 3.2 & 0.0 & 22.0 & 0.0 & 1.2 & 0.0 & 0.0 & 1.9 & 0.0 & 0.0 \\
\hline
\end{tabular}


(a)

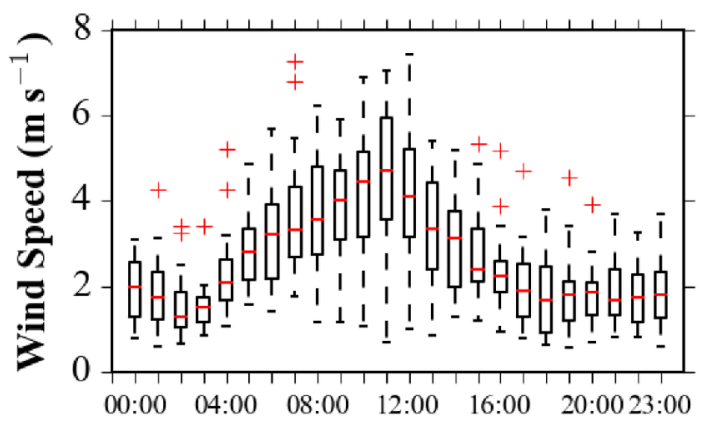

(c)

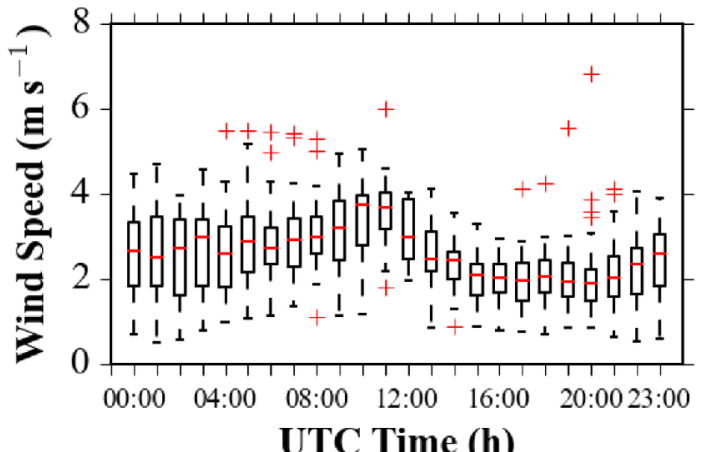

(b)

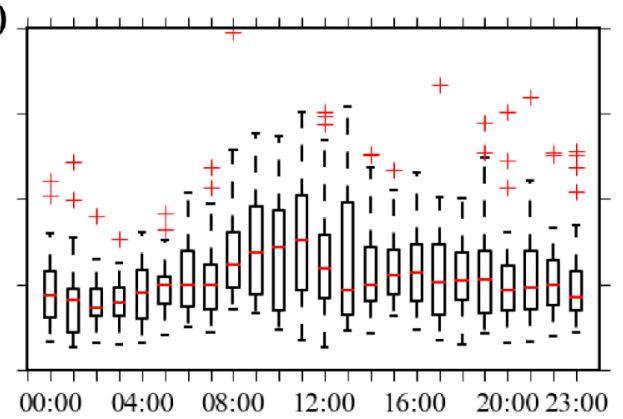

(d)

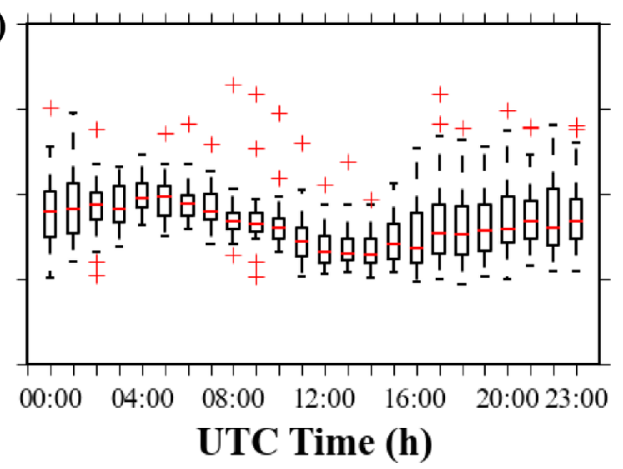

Fig. 5. Diurnal wind speed in $\mathrm{m} \mathrm{s}^{-1}$ (a) pre-monsoon, (b) monsoon, (c) post-monsoon, and (d) winter. The red-crosses are the outliers that have a value greater than 1.5 times the interquartile (IQ) range. Note that time axes are mentioned in UTC (local time $=$ UTC time $+5: 45 \mathrm{~h})$.

(a)

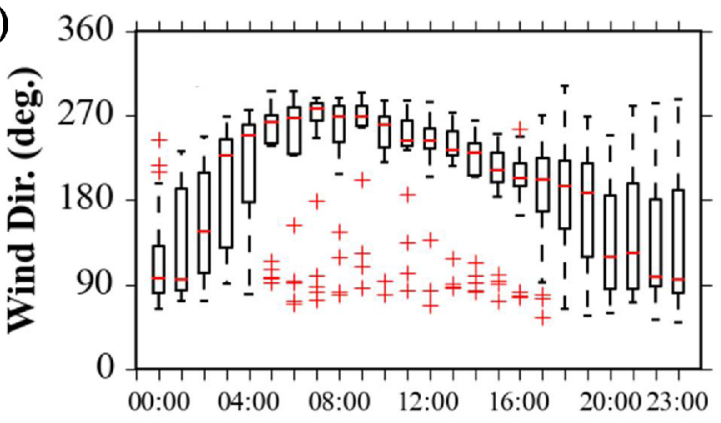

(c)

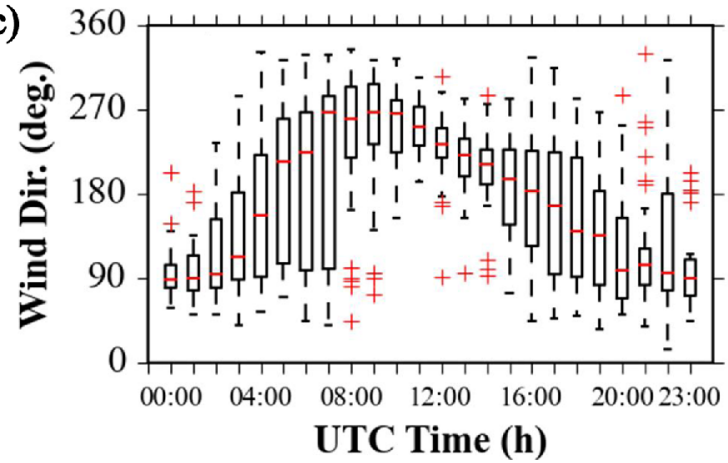

(b)

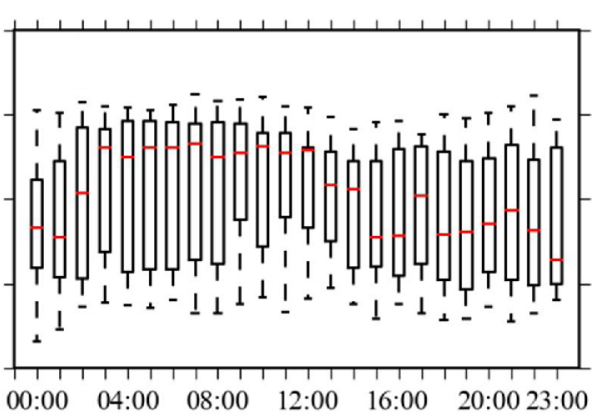

(d)

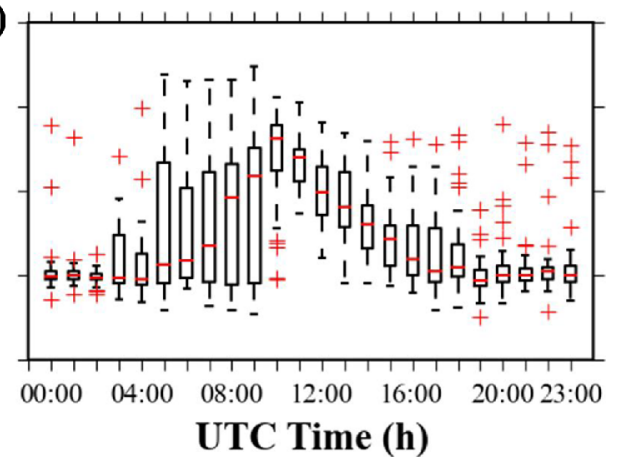

Fig. 6. Same as Fig. 5 but for wind direction.

were found with one in the morning ( $\sim 0600$ LST) and another in the afternoon ( 1600 LST). The afternoon peak was more pronounced than the morning peak. Both peaks are statistically significant at the $95 \%$ confidence interval. During the early morning (i.e. before occurrence of the morning peak) light winds $\left(<10 \mathrm{~km} \mathrm{hr}^{-1} \sim 2.77 \mathrm{~m} \mathrm{~s}^{-1}\right)$, which shifted direction from 
(a)

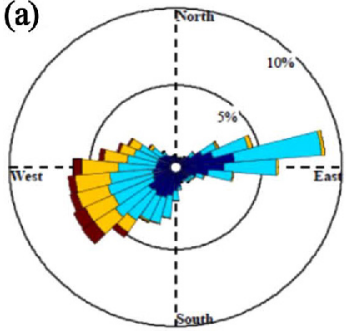

(b)

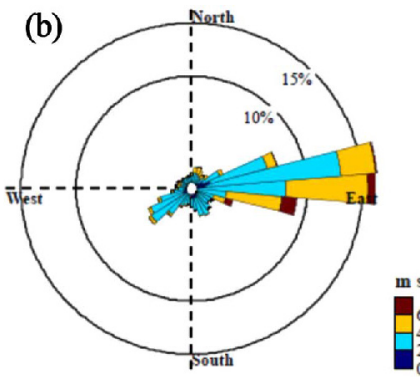

Fig. 7. Wind rose diagrams (a) pre-monsoon, and (b) winter season.

SW to SE, blew from the surrounding hills as a continuation of the general katabatic flows. As Nagarkot has a west facing exposure on the foot-hill wall, its air remains cooler than the opposite east facing wall, which influences warmer air flow contribution to the katabatic flow. During the day Nagarkot begins to be influenced by upslope flow and wind speeds gradually increase reaching maximum strength during the afternoon. The mean morning and afternoon peaks were 2.1 $\mathrm{m} \mathrm{s}^{-1}$ and $4.8 \mathrm{~m} \mathrm{~s}^{-1}$, respectively.

We observe upslope flow starts earlier in the pre-monsoon than in the other seasons. The morning fog associated with the temperature inversion dissipated earlier in the pre-monsoon which likely contributes to generation of the early onset of upslope flows. The SW wind from morning to dusk (Fig. 6a), which sometimes persisted until midnight, was associated with upslope and up-valley winds flowing through the Bagmati River gorge, which is located in the SW of the valley, and by gap winds through the western passes (Bhimdhunga and Nagdhunga) of the valley. Previous research (Panday and Prinn, 2009; Regmi et al., 2002) also observed these winds from the passes.

During the monsoon season we observe significant daily variability in wind direction. Figure $6 \mathrm{~b}$ shows the wind direction quartile range is significantly higher in the monsoon period than in any other season. Winds were generally calm to light throughout the day but still displayed a clear diurnal cycle with a mean morning (afternoon) peak $1.9 \mathrm{~m} \mathrm{~s}^{-1}\left(3.2 \mathrm{~m} \mathrm{~s}^{-1}\right)$ occurred around 0500 (1500) LST (Fig. 5b). The maximum gusts in this period could exceed $25 \mathrm{~m} \mathrm{~s}^{-1}$ during the afternoon at the beginning of the season. This is consistent with the transition from the end of the pre-monsoon to early monsoon period which is characterized by a stronger atmospheric circulation and generation of severe thunderstorm and lightning activity.
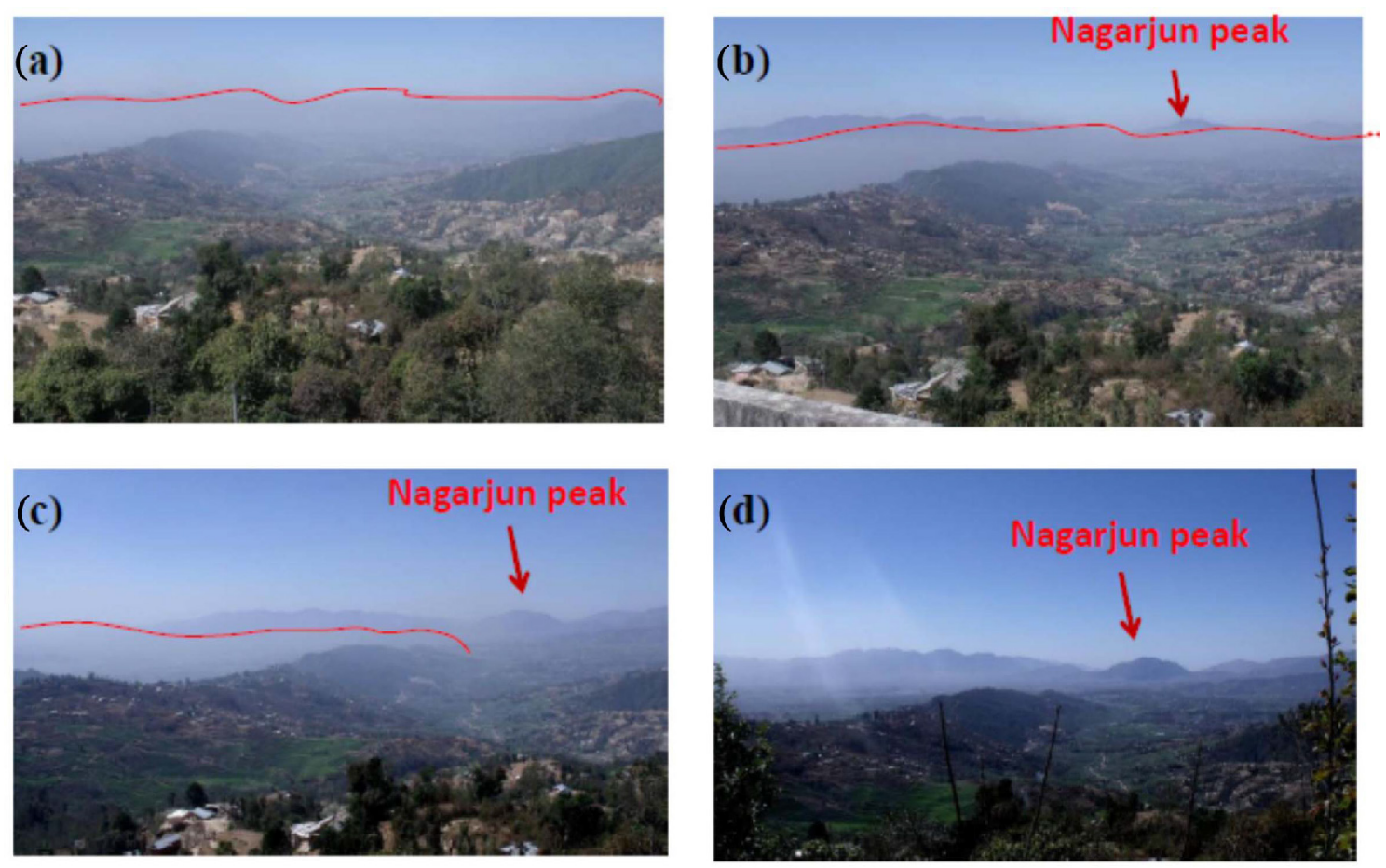

Fig. 8. (a) Photograph taken on 28 February 2011 in the late morning from the Nagarkot station looking towards the west of the Kathmandu valley. The "brown haze" layer, indicated by the red line, fully covered the Nagarjun peak (2,100 m asl). (b) Photograph taken on 8 March 2011 in the late morning. The Kathmandu Valley is completely covered by "brown haze". However the vertical extent of the haze layer remains below that of the surrounding mountains. (c) Photograph taken on 8 March 2011 in the early afternoon. The western passes of the Kathmandu Valley Bhimdhunga and Nagdhunga are relatively haze free compared to the SW of the valley indicating the westerly wind has swept pollutants through the eastern passes to the neighbouring Dhulikhel and Banepa Valleys. (d) Photograph taken on 8 March 2011 during middle of the afternoon showing the aftermath of westerly winds dispersing the pollution. 
In the post-monsoon season wind patterns also show a clear diurnal cycle with twin wind speed peaks, one in the morning ( $\sim 0500$ LST) and the other in the afternoon ( 1500 LST) (Fig. $5 \mathrm{c})$. The NE (SW) wind with average speed $3 \mathrm{~m} \mathrm{~s}^{-1}\left(3.75 \mathrm{~m} \mathrm{~s}^{-1}\right)$ was recorded during the morning (afternoon) peak. Our analysis showed that the SW wind was predominant from late morning to late evening (Fig. 6c).

In the winter, unlike the other seasons, wind speed patterns are very different with no afternoon peak. Easterly winds were dominant until the middle of the morning which is consistent with continuation of katabatic flow as explained above. Fig. $6 \mathrm{~d}$ shows that a SW flow begins later in the morning, attributed to the reduced solar heating at the surface during winter, delaying the onset of upslope flow. Delayed initiation of the upslope flow was also caused by the prolonged winter morning fog associated with the strong cold air pool and temperature inversion that formed in the valley. The SW wind remains for only a short period of time, moves to SE in the early evening before veering to a downslope easterly wind, suggesting that the warming of the valley atmosphere plays a significant role in perturbing the circulation at this time of year. In contrast to the other seasons, where strong winds occurred during the afternoon, winds were strongest during the morning, typically $\sim 4 \mathrm{~m} \mathrm{~s}^{-1}$, whilst slightly weaker winds, $\sim 3 \mathrm{~m} \mathrm{~s}^{-1}$, were experienced during late afternoon. Strong gusts were also recorded during the early morning period, exceeding $\sim 14 \mathrm{~m} \mathrm{~s}^{-1}$.

The atmospheric pressure measurements (not shown) display a clear diurnal cycle throughout the year. Daily twin high pressure peaks occurred at 0900 and 2100 LST and low pressure systems developed at 1500 LST and 0300 LST in almost all seasons. The magnitude of the peaks is lowest during the monsoon season and highest during the winter time. The diurnal fluctuation was more pronounced than the nocturnal variation. The maximum daytime fluctuation was $\sim 3.5$ $\mathrm{hPa}$ during the pre-monsoon season while the minimum night time fluctuation of $\sim 1.6 \mathrm{hPa}$ was found in the monsoon season.

The temperature variation at the mid-hill station site shows clear diurnal cycles with a maximum temperature during the afternoon ( $1400 \mathrm{LST})$, as expected, and lowest temperatures during the early morning ( $\sim 0500$ LST) all year round. The maximum diurnal fluctuation in temperature was $7.3^{\circ} \mathrm{C}$ in March (pre-monsoon season) and the minimum was $3.6^{\circ} \mathrm{C}$ in July (monsoon season). In the pre-monsoon season average diurnal maximum, diurnal minimum and daily temperatures were $25.4^{\circ} \mathrm{C}, 6.6^{\circ} \mathrm{C}$ and $16.0^{\circ} \mathrm{C}$, respectively. Similarly, in the monsoon season the corresponding temperatures were $24.9^{\circ} \mathrm{C}$, $13.2^{\circ} \mathrm{C}$ and $18.6^{\circ} \mathrm{C}$, respectively. In the winter season the daytime maximum temperature was $17.3^{\circ} \mathrm{C}$ whereas early morning minimum temperature was $4.0^{\circ} \mathrm{C}$.

Consistent with the temperature profile explained above, the diurnal cycle of relative humidity (RH) reveals (not shown) a minimum $\mathrm{RH}$ in the afternoon and maximum in the early morning. The difference between maximum and minimum $\mathrm{RH}$ was highest in March (>33\%), whereas the minimum difference $(10 \%)$, occurred in July. On average, March is the driest and July is the most humid month at this altitude over the year based on these recordings.

In the pre-monsoon season the average maximum, minimum and daily $\mathrm{RH}$ were $91.3 \%, 12.2 \%$ and $62.8 \%$, respectively. During the monsoon season RH generally increases throughout the day. Diurnal average maximum, minimum and daily $\mathrm{RH}$ were $93.2 \%, 35.4 \%$ and $84.1 \%$, respectively, in this season. The RH then begins to decline from the beginning of the postmonsoon season. In general this season remained relatively dry during the day with clear nights. Average maximum, minimum and daily $\mathrm{RH}$ were $93.2 \%, 20.8 \%$ and $76.3 \%$, respectively, during this season. In the winter season the corresponding $\mathrm{RH}$ were $93.2 \%, 14.6 \%$ and $67.1 \%$, respectively.

\section{b. Aerosol}

\section{(1) Seasonal variation}

Figure 9 shows the time series analysis and size distribution of aerosol measured during the experiment. Table 2 provides the statistical summary of the measurements. During the premonsoon season the coarse particle concentration $\left(D_{P}>2.5\right.$ $\mu \mathrm{m}$ ) was less than $50 \mathrm{~cm}^{-3}$ in most cases but could reach up to $250 \mathrm{~cm}^{-3}$ in some extreme cases. The concentration for fine particles $\left(0.25<\mathrm{D}_{\mathrm{p}}<2.5 \mu \mathrm{m}\right)$ was dominant in this season (average: $641 \pm 424 \mathrm{~cm}^{-3}$ ), which is slightly lower than particle concentration observed in the city center $\left(672 \mathrm{~cm}^{-3}\right.$, Paknajol, Kathmandu, Alt: 1,380 m asl) (Putero et al., 2015), and able to contribute up to $99 \%$ according to the seasonal mean data. At Dhulikhel city (Alt: $1,510 \mathrm{~m}$ asl), a small valley in the east (see Fig. 1), however, fine particle concentration $(30-340 \mathrm{~nm})$, as reported in Shrestha et al. (2010), was significantly greater $\left(5,344 \pm 3,355 \mathrm{~cm}^{-3}\right)$ than in the Kathmandu Valley. A sig-

(a)

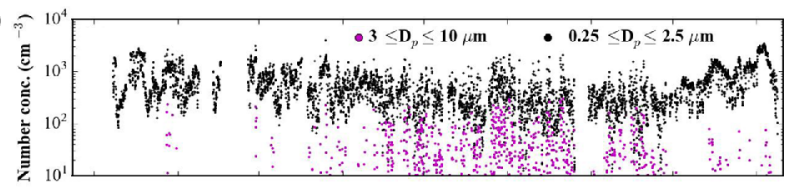

(b)

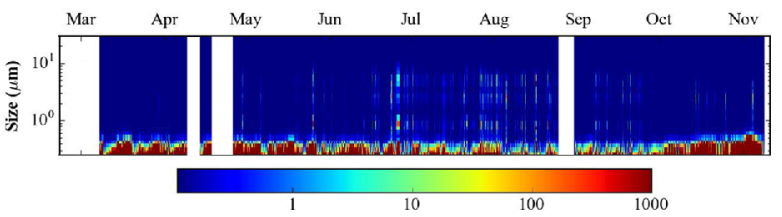

(c)

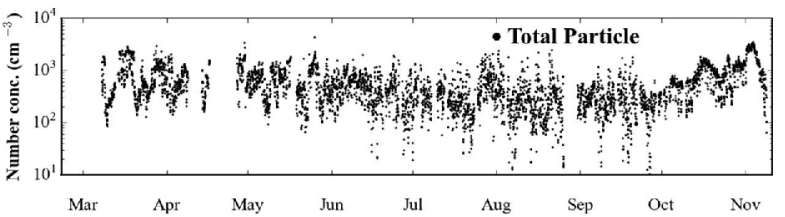

Fig. 9. Time series analysis of particle concentration (hourly average data) showing (a) fine particle concentration $\left(0.25 \leq \mathrm{D}_{\mathrm{p}}\right.$ $\leq 2.5 \mu \mathrm{m})$, and coarse particle concentration $\left(3.0 \leq \mathrm{D}_{\mathrm{p}} \leq 10 \mu \mathrm{m}\right)$ $\left(\mathrm{cm}^{-3}\right)$, (b) aerosol number concentration $\left(\mathrm{cm}^{-3}\right)$ as a function of particle size $(\mu \mathrm{m})$, and $(\mathrm{c})$ total aerosol concentration $\left(\mathrm{cm}^{-3}\right)$. Concentration of particles with diameter greater than $10.0 \mu \mathrm{m}$ was less than one throughout the measurement. 
Table 2. Statistics of pollutants at Nagarkot, Nepal.

\begin{tabular}{|c|c|c|c|c|c|c|c|c|c|c|c|c|c|c|c|}
\hline \multirow{2}{*}{ Aerosol data } & \multicolumn{5}{|c|}{ Pre-monsoon (March-May) } & \multicolumn{5}{|c|}{ Monsoon (June-September) } & \multicolumn{5}{|c|}{ Post-Monsoon (October-November) } \\
\hline & Mean & Min & Max & Median & $1 \sigma$ & Mean & Min & Max & Median & $1 \sigma$ & Mean & Min & Max & Median & $1 \sigma$ \\
\hline $\begin{array}{l}\text { Total particle conc. } \\
\qquad\left(\mathrm{cm}^{-3}\right)\end{array}$ & 644 & 65 & 4157 & 550 & 429 & 293 & 5 & 1732 & 252 & 205 & 775 & 115 & 1990 & 653 & 417 \\
\hline $\begin{array}{c}\text { Fine particle } \\
\left(0.25 \leq \mathrm{D}_{\mathrm{p}} \leq 2.5 \mu \mathrm{m}\right)\end{array}$ & 641 & 65 & 3934 & 548 & 424 & 286 & 5 & 1590 & 250 & 191 & 773 & 115 & 1925 & 651 & 415 \\
\hline $\begin{array}{l}\text { Coarse particle } \\
\left(D_{p}>2.5 \mu \mathrm{m}\right)\end{array}$ & 3 & 0 & 223 & 0 & 13 & 7 & 0 & 142 & 0 & 20 & 2 & 0 & 65 & 0 & 7 \\
\hline $\mathrm{PM}_{10}\left(\mu \mathrm{g} \mathrm{m}^{-3}\right)$ & 195.9 & 3.53 & 325.6 & 32.95 & 126 & 656 & 0.4 & 1250.50 & 16.03 & 560.3 & 117.27 & 3.02 & 565.3 & 26 & 435.86 \\
\hline
\end{tabular}

(a)

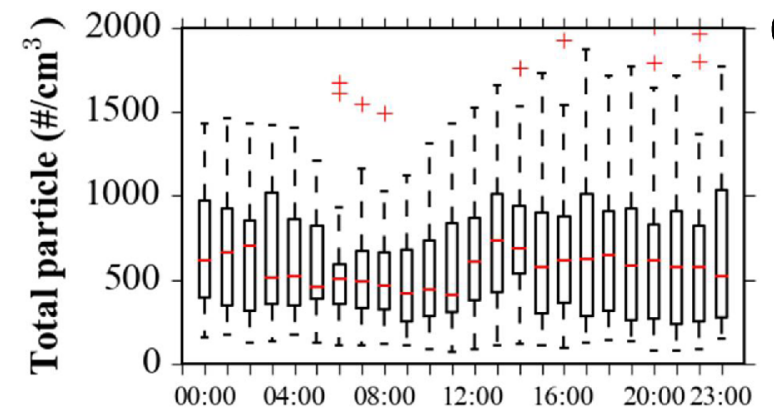

(c)

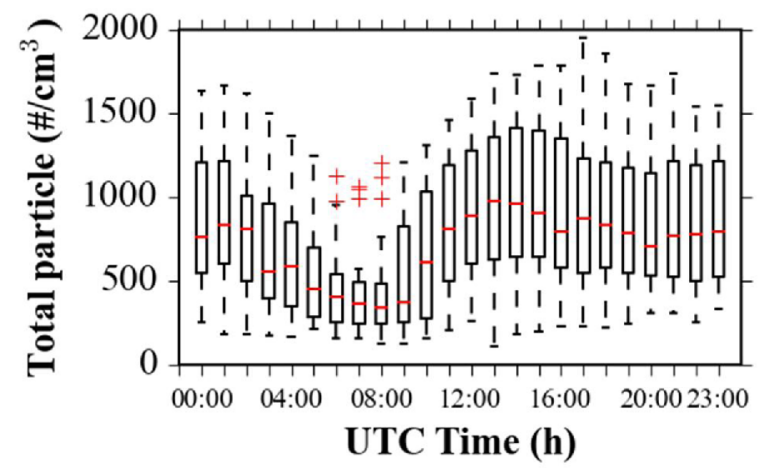

(b)

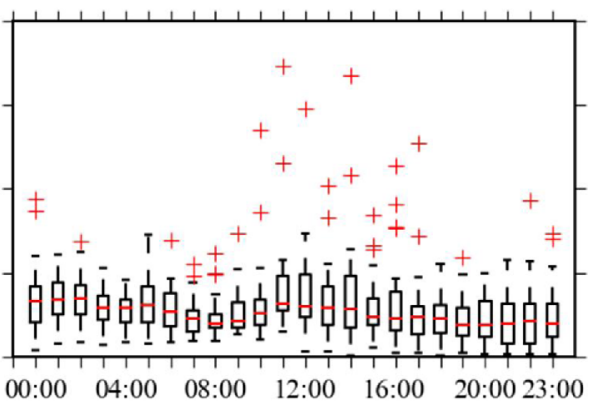

UTC Time (h)

Fig. 10. Diurnal variation of total particle concentrations observed during the a) pre-monsoon, b) monsoon and c) postmonsoon seasons. The red-crosses are the outliers that have a value greater than 1.5 times the interquartile (IQ) range. Note that time axes are mentioned in UTC (local time $=$ UTC time $+5: 45 \mathrm{~h}$ ).

nificant contribution of fine particle $(10-700 \mathrm{~nm})$ concentration (average: $\sim 1300 \mathrm{~cm}^{-3}$ ) in the pre-monsoon season was observed in the high Himalayas (NCO-P, 5,079 m asl) (Venzac et al., 2008).

Figures 9a-9b show that during the monsoon season the frequency and concentration of coarse particles increase substantially (up to $10 \%$ ) whereas the fine particle contribution shows a slight decreasing trend over time. Total particle concentrations in this season (average: $293 \pm 205 \mathrm{~cm}^{-3}$ ) were lower than other seasons (Fig. 9c), which is slightly higher than $\left(250 \mathrm{~cm}^{-3}\right)$ the concentration at the Paknajol site as reported by Putero et al. (2015), suggesting that the monsoon rain plays a significant role in scavenging pollutants as expected. This effect has been observed in central (Shrestha et al., 2010) and high altitude regions (5,079 m) (Marinoni et al., 2010) of Nepal.

The post-monsoon season is characterized by the most polluted season with mean particle concentrations of $775 \mathrm{~cm}^{-3}$ which were dominated by fine particles $(\sim 99 \%)$ ). During this season the total particle concentration generally began to increase but also revealed an interesting sub-seasonal monthly cycle. For example both coarse and fine particle concentrations reached their peak in the mid-October and declined during the end of that month and so on. Maximum total aerosol concentration in this season at Nagarkot was observed to be $1990 \mathrm{~cm}^{-3}$ whereas peak concentration of fine particle in the high Himalayas (NCO-P) was $2000 \mathrm{~cm}^{-3}$ (Venzac et al., 2008).

\section{(2) Diurnal variation}

Figure 10a shows, in the pre-monsoon season, total particle concentrations exhibit distinct diurnal twin peaks, one in the morning (0700-0800 LST) and the other in the evening (19002000 LST). The evening peak (average: $747 \mathrm{~cm}^{-3}$ ) is generally 

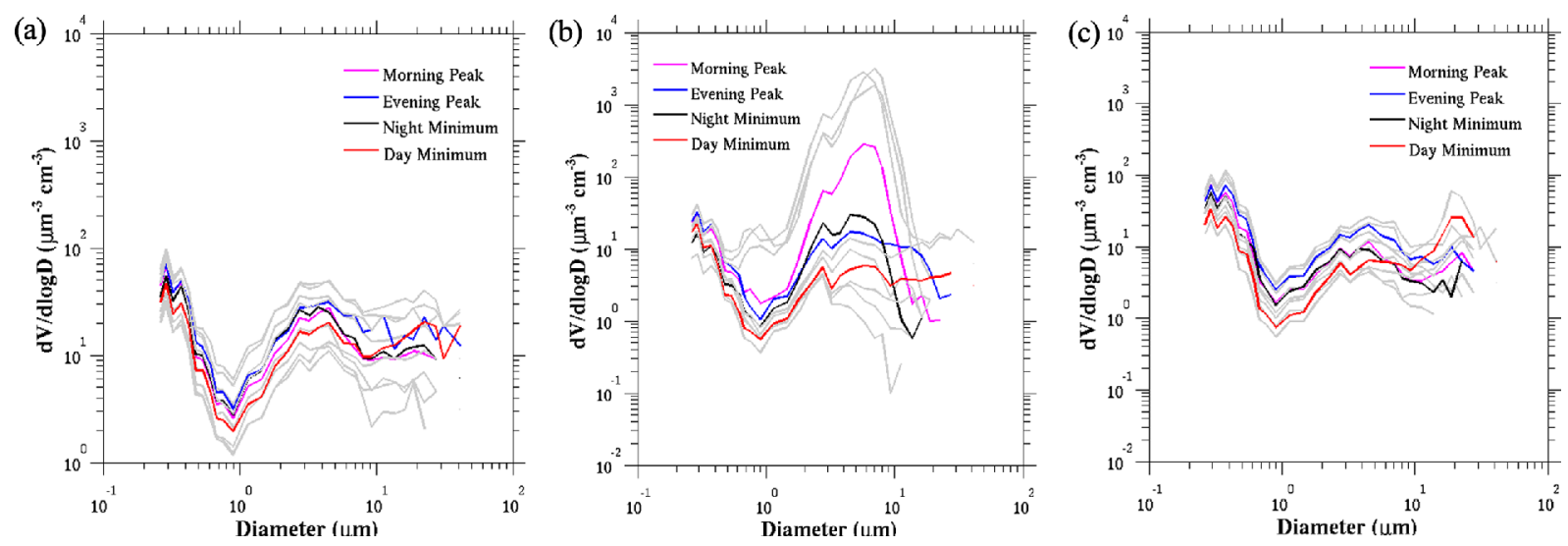

Fig. 11. Volume distribution of aerosol particles (a) pre-monsoon, (b) monsoon, and (c) post-monsoon season. Color lines represent mean volume distribution and grey lines stand for one standard deviation $(1 \sigma)$.

more pronounced than the morning peak (average: $680 \mathrm{~cm}^{-3}$ ), which is the opposite behaviour to the observed pattern at Paknajol site, as reported in Putero et al. (2015). The nocturnal concentration is higher than the diurnal pollutant concentration. However, these peaks are not statistically significant at the $95 \%$ confidence interval. The maximum and minimum evening peak concentrations, based on hourly averaged data, were $\sim 1,600 \mathrm{~cm}^{-3}$ and $\sim 200 \mathrm{~cm}^{-3}$, respectively, suggesting a significant intra-seasonal variability of pollutant concentration in the Kathmandu Valley.

A diurnal cycle analysis of aerosol concentration during weekdays and weekends shows the consistent occurrence of peaks at the same time in both cases with slightly lower concentration during weekends in the pre-monsoon season. This indicates that these peaks are not consistent with peak flow of traffic in the Kathmandu Valley. Discounting transitory events, concentration was $\sim 500 \mathrm{~cm}^{-3}$ and this appears to represent a typical background level for aerosols during the pre-monsoon season at this altitude. This is consistent with a wind-pollution rose analysis as shown in Fig. 12a. We also analyze the variation in particle size distributions recorded in the morning and evening peak periods (Fig. 13a). Although the fine and accumulation mode particles $(0.1-1 \mu \mathrm{m})$ are dominant during both, the contributions of coarse mode particles are largest during the morning peak than in the evening peak.

$\mathrm{PM}_{10}$ mass loadings were also estimated (assuming perfectly spherical particles with average density of $1.5 \mathrm{~g} \mathrm{~cm}^{-3}$, not shown). This again showed that the $\mathrm{PM}_{10}$ followed a similar diurnal cycle as the total particle concentration with daily twin peaks in the morning (maximum $\sim 68.5 \mu \mathrm{g} \mathrm{m}^{-3}$ ) and other in the evening (maximum $98.9 \mu \mathrm{g} \mathrm{m}^{-3}$ ). However, these peaks are not statistically significant at the $95 \%$ confidence interval. Average $\mathrm{PM}_{10}$ concentration in the pre-monsoon season ( 195.9 $\mu \mathrm{g} \mathrm{m}^{-3}$ ) is similar to previous observations in the sub-urban area (Aryal et al., 2008) and city center $\left(169.3 \mu \mathrm{g} \mathrm{m}^{-3}\right)$ (Putero et al., 2015) of the Kathmandu Valley but less than in Raipur city, India (306.1 $\mathrm{g} \mathrm{m}^{-3}$ ) (Deshmukh and Deb, 2013). Volume distributions show the diurnal peak (non-peak) of the particle number concentration are mainly driven by the presence (absence) of coarse particles (Fig. 11a) in this season.

In the monsoon season, as shown in Fig. 10b, we observe evening and morning peaks during 1700-1800 LST and 07000800 LST, respectively, almost the same as in the previous season. The morning (evening) peak concentration during the monsoon onset period, based on hourly average data, was more than $575 \mathrm{~cm}^{-3}\left(580 \mathrm{~cm}^{-3}\right)$, which decreased over time to $<360 \mathrm{~cm}^{-3}\left(330 \mathrm{~cm}^{-3}\right)$ during the end of the season, with an average over the season of $348 \mathrm{~cm}^{-3}\left(425 \mathrm{~cm}^{-3}\right)$. These peaks are statistically significant at the $95 \%$ confidence interval. The minimum particle concentration during the monsoon season was $175 \mathrm{~cm}^{-3}$ indicating a very low background particle concentration during this season, also shown in the wind-pollution rose (Fig. 12b). Diurnal patterns of particle number concentration during weekdays and weekends are quite similar in this season. A significant contribution of coarse particles is observed in the monsoon season. This is consistent with size and volume distribution as shown in Fig. 13b and Fig. 11b, respectively, where the areas under the distribution curves are considerably increased as compared to the other seasons.

We observe a slightly different signature for $\mathrm{PM}_{10}$ during the monsoon season, however it still shows a clear diurnal variation with a morning and an evening peak. Average evening (morning) peak concentration was around $300 \mu \mathrm{g} \mathrm{m}^{-3}$ (600 $\left.\mu \mathrm{g} \mathrm{m}^{-3}\right)$, although not statistically significant at the $95 \%$ confidence interval. Average concentration was $656 \mu \mathrm{g} \mathrm{m}^{-3}$, which is higher than the previous observation in the peri-urban area of the Valley (Aryal et al., 2008) and at Raipur city, India (Deshmukh and Deb, 2013). In this case it must be emphasised that the calculated $\mathrm{PM}_{10}$ concentrations are based in the usual manner on in-situ derived single particle scattering cross section which assumes equivalent spherical aerosol, and which may have grown hygroscopically (Kajino et al., 2006). The diurnal minimum $\mathrm{PM}_{10}$ was around $15 \mu \mathrm{g} \mathrm{m}^{-3}$ whereas the night time concentration was always greater than $60 \mu \mathrm{g} \mathrm{m}^{-3}$. Nocturnal higher background concentrations are attributed to the presence of coarse particles. 

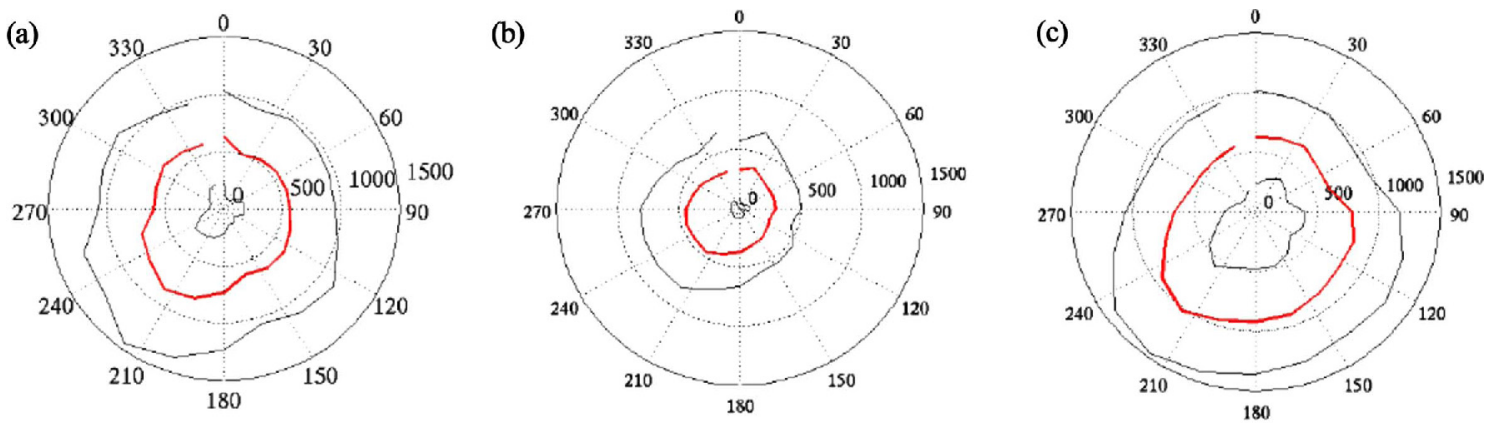

Standard deviation $(1 \sigma)$

Mean

Fig. 12. Wind-pollution rose diagrams (a) pre-monsoon, (b) monsoon, and (c) post-monsoon season.
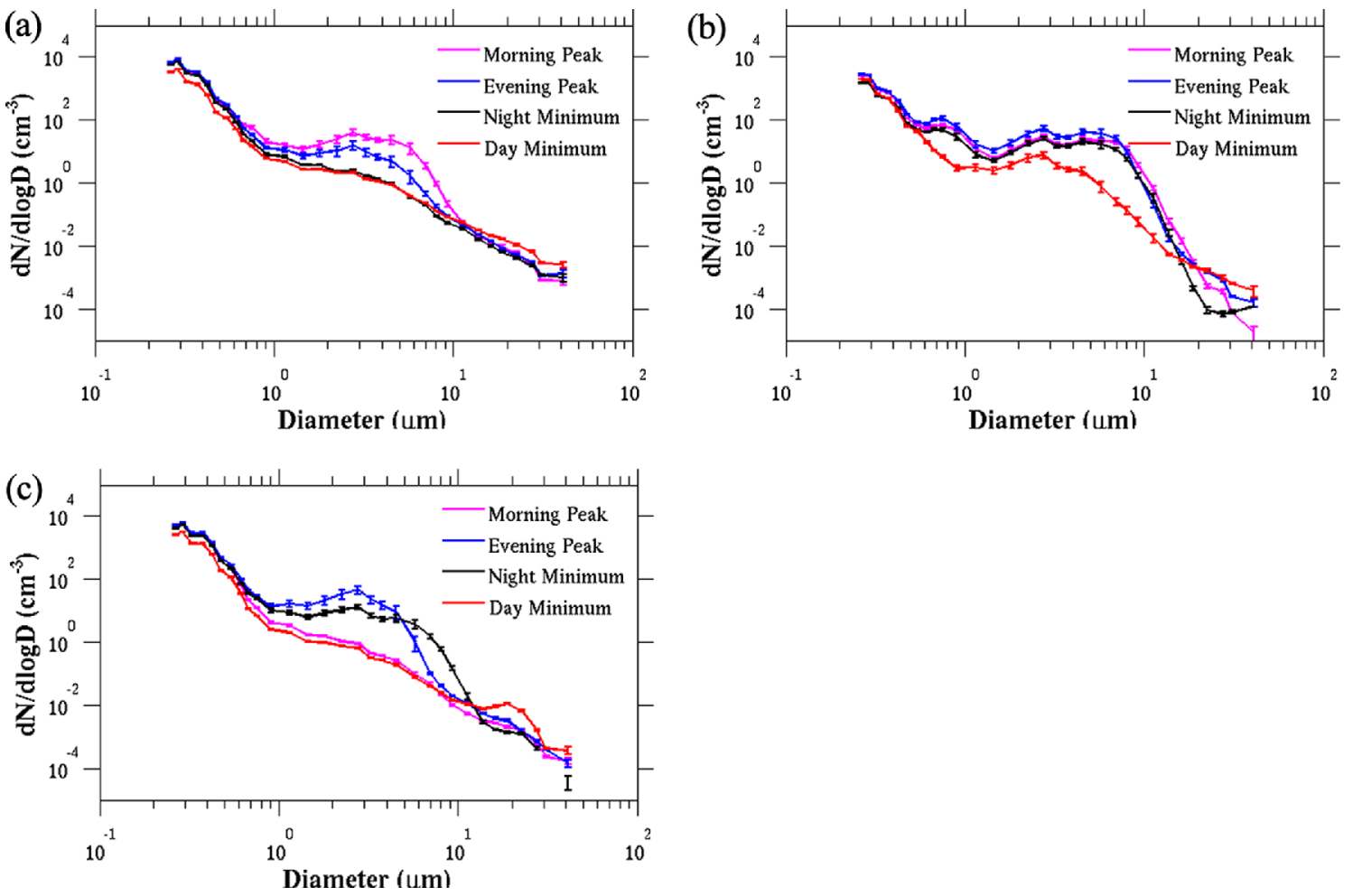

Fig. 13. Size distribution of aerosols showing contribution of different sizes of particles for the peaks and minimum and maximum particle concentration periods during (a) pre-monsoon, (b) monsoon, and (c) post-monsoon season.

We also find similar daily twin peaks, one in the morning and the other in the evening in the post-monsoon season (Fig. 10c). The evening peak (average: $981 \mathrm{~cm}^{-3}$ ), which is statistically significant at the $95 \%$ confidence interval, is higher than the morning peak (average: $886 \mathrm{~cm}^{-3}$ ), but is not significant at the $95 \%$ confidence interval. The nocturnal minimum concentration $\left(625 \mathrm{~cm}^{-3}\right)$ is almost double the diurnal minimum concentration $\left(330 \mathrm{~cm}^{-3}\right)$. The enhanced evening and nocturnal pollution concentrations are attributed to an increase in coarse size particles (Fig. 13c), indicating increased background pollution concentration as shown in the wind-pollution rose (Fig. 12c). The morning and evening peak particle concentrations during weekends were slightly higher than in weekdays. The $\mathrm{PM}_{10}$ concentration follows a similar pattern to the total particle concentration with a morning and an evening peak of, $43 \mu \mathrm{g} \mathrm{m}^{-3}$ and $49 \mu \mathrm{g} \mathrm{m}^{-3}$, respectively, which are significant at the $95 \%$ confidence interval.

\section{Conclusions}

From March to December 2011, aerosol number size distributions $(0.25 \mu \mathrm{m}-32 \mu \mathrm{m})$, wind speed and direction, tem- 
perature, relative humidity, atmospheric pressure and rainfall were continuously measured at Nagarkot (Lat: $27.7^{\circ} \mathrm{N}$, Lon: $85.5^{\circ} \mathrm{E}$, Alt: $1,900 \mathrm{~m}$ asl), Nepal, located in the eastern flank of a bowl shaped Kathmandu Valley. Our results show a distinct seasonal and diurnal cycle of aerosol in the valley. We observe daily twin peaks throughout the year, one in the morning and the other in the evening. The maximum aerosol number concentration, dominated by the fine particles $\left(0.25 \mu \mathrm{m} \leq \mathrm{D}_{\mathrm{P}} \leq\right.$ $2.5 \mu \mathrm{m})$, occurs during the dry season whereas seasonal minimum particle concentration with a significant contribution of coarse particles $\left(3.0 \mu \mathrm{m} \leq \mathrm{D}_{\mathrm{p}} \leq 10.0 \mu \mathrm{m}\right)$ occurs during the monsoon season (June-September). This may be attributed to hygroscopic growth of the aerosol particles (Kajino et al., 2006), however contributions by particles larger than $10.0 \mu \mathrm{m}$ is negligible throughout the year. Our analysis shows that the post-monsoon (October-November) season (average: $775 \pm 417$ $\mathrm{cm}^{-3}$ ) was the most polluted followed by the pre-monsoon (March-May) (average: $644 \pm 429 \mathrm{~cm}^{-3}$ ) and the monsoon season (average: $293 \pm 205 \mathrm{~cm}^{-3}$ ). The Kathmandu Valley receives significant $\mathrm{PM}_{10}$ input during the monsoon season which is contributed to by coarse particles from local sources.

The diurnal peaks in aerosol concentration are attributed to morning calm wind conditions followed by the transitional growth and break down of the nocturnal boundary layer. We find that both peaks are influenced by enhancement of the coarser particles. The evening peak, is generally higher than the morning peak, and is caused by the light SW winds blowing through the Kathmandu Valley carrying fresh evening emissions from increased local activities and suppression of the mixing layer, which re-circulates aged pollutants. Diurnal cycle analysis of aerosol number concentration during weekdays and weekends also supports the conclusion that the peaks are not consistent with rush traffic hour and hence multiple sources in addition to traffic emission are very likely responsible for regulating the aerosol concentration within the valley.

A number of previous studies in the Kathmandu Valley have also suggested that the peaks may be caused by boundary layer processes (Shrestha et al., 2010) and pollutant recirculation (Panday and Prinn, 2009). Our study at higher altitude supports this hypothesis with the morning peak strongly influenced by the growth of the mixing layer. Furthermore, air masses transported by up-valley wind from the neighbouring eastern and southeastern valleys, as suggested by the diurnal wind patterns, contribute to the morning pollution peak. The low concentrations observed during the afternoon are attributable to the strong south-westerly wind that sweeps away the valley's pollutants towards the eastern passes. This ventilation mechanism, where cooler air from neighbouring valleys suppresses the mixed layer and strong westerly wind forces the pollutants to pass through the Nala and Sanga passes, has been highlighted in a previous modelling study of the Kathmandu Valley (Panday et al., 2009). The nocturnal high aerosol concentrations are caused by a combination of a stable atmosphere enhanced by shallow boundary layer height and convergence of katabatic wind, which further raises the level to which the valley's pollutants can be transported.

Panday et al. (2009) proposed several mechanisms for dispersion of pollutants out of the Kathmandu Valley. Similar to their findings, our seasonal observations, supported by case study analysis, has allowed further interpretation and understanding of the key aerosol transport processes, highlighting the presence of multiple mechanisms acting to remove pollutants from the valley (Fig. 8). Based on our observations we suggest the dominant processes that contribute to remove pollutants out of the valley are:

i) Gap flow through the western passes of the Kathmandu Valley, and

ii) Thermally driven mountain-valley circulation.

The gap flow is dominant during the afternoon period. The valley consists of a number of passes in the western and eastern rims that bring strong westerly winds into the valley. Westerly winds from the Bhimdhunga and Nagdhunga passes then aid dispersal of the valley pollutants via the eastern passes (Nala and Sanga). Our observations also demonstrate that SW winds from late morning to evening are dominant almost throughout the year, consistent with the direction in which these passes lie in relation to the station. Figure $8 \mathrm{c}$ shows that when strong westerly wind fully developed, the western part of the valley is free from haze whereas the eastern part still retains pollutants.

In the mountain-valley circulation night time pollutants are transported to higher levels due to the convergence of katabatic flow at the valley bottom. This mechanism, however, may not fully ventilate the pollutants from of the valley, and consequently the pollutants can be retained within the mountain rim. This may be the reason that we observe nocturnal high concentrations at Nagarkot which is the reverse of the behaviour seen in particle concentration at Paknajol (city center). A similar, thermally-driven mechanism was also observed in the lower Fraser valley in British Columbia, Canada, (Martilli and Steyn, 2004; Borrego and Norman, 2007).

While this study represents a limited set of field measurements, with conclusions being drawn based on only a single station, we hope the results may contribute to understanding local air pollution and its vertical transport in the Kathmandu region. A detailed investigation of aerosol chemical composition would add significantly to the interpretation and identification of local sources and residence times of these pollutants within the valley and to assess contributions to and from its inter-valley transport. This would assist in developing abatement strategies for this rapidly developing region.

Acknowledgements. This study was carried out under the $\mathrm{Ph}$.D. funding of sustainable consumption institute (SCI), University of Manchester in collaboration with Institute of Engineering (IOE), Pulchowk Campus, Nepal as foreseen in the memorandum of understanding between the University of Manchester and IOE signed in 2010. The authors would like to thank the staff working at the Nagarkot community health center for their cooperation during setting up and taking care 
of the instruments throughout the field experiment. We would like to thank Dr. Binod Bhattarai, Dr. R.K. Sharma and Suranjan Sharma from IOE for their valuable support throughout the field experiment. We extended special thanks to Dr. Michael Flynn and Dr. Karl Beswick for their cooperation before and during the experiment. The authors would appreciate the anonymous reviewers' constructive comments and suggestions.

\section{Edited by: Song-You Hong, Kim and Yeh}

\section{Reference}

ADB/ICIMOD, 2006: Environment Assessment of Nepal: Emerging Issues and Challenges. Asian Development Bank / International Centre for Integrated Mountain Development (ICIMOD), 225 pp.

Akimoto, H., 2003: Global air quality and pollution. Science, 302, 17161719.

Alford, D., 1992: Hydrological Aspects of the Himalayan Region. ICIMOD, $81 \mathrm{pp}$.

Aryal, R. K., B.-K. Lee, R. Karki, A. Gurung, J. Kandasamy, B. K. Pathak, S. Sharma, and N. Giri, 2008: Seasonal PM10 dynamics in Kathmandu Valley. Atmos. Environ., 42, 8623-8633.

Beniston, M., 1987: A numerical study of atmospheric pollution over complex terrain in Switzerland. Bound-Lay. Meteorol., 41, 75-96.

Brulfert, G., C. Chemel, E. Chaxel, J. P. Chollet, B. Jouve, and H. Villard, 2006: Assessment of 2010 air quality in two Alpine valleys from modelling: Weather type and emission scenarios. Atmos. Environ., 40, 7893-7907.

Carrico, C. M., M. H. Bergin, A. B. Shrestha, J. E. Dibb, L. Gomes, and J. M. Harris, 2003: The importance of carbon and mineral dust to seasonal aerosol properties in the Nepal Himalaya. Atmos. Environ., 37, 28112824.

Deshmukh, D. K., and M. K. Deb, 2013: Size distribution and seasonal variation of size-segregated particulate matter in the ambient air of Raipur city, India. Air Qual. Atmos. Health, 6, 259-276.

Gautam, R., and Coauthors, 2011: Accumulation of aerosols over the IndoGangetic plains and southern slopes of the Himalayas: distribution, properties and radiative effects during the 2009 pre-monsoon season. Atmos. Chem. Phy., 11, 12841-12863.

Grigoras, G., V. Cuculeanu, G. Ene, G. Mocioaca, and A. Deneanu, 2012: Air pollution dispersion modeling in a polluted industrial area of complex terrain from Romania. Rom. Rep. Phys., 64, 173-186.

Guo, J., S. Kang, J. Huang, Q. Zhang, L. Tripathee, and M. Sillanpaa, 2015: Seasonal variations of trace elements in precipitation at the largest city in Tibet, Lhasa. Atmos. Res., 153, 87-97.

Gurung, A., and M. L. Bell, 2013: The state of scientific evidence on air pollution and human helath in Nepal. Environ. Res., 124, 54-64.

Hindman, E. E., and B. P. Upadhayay, 2002: Air pollution transport in the Himalayas of Nepal and Tibet during the 1995-1996 dry season. Atmos. Environ., 36, 727-739.

Kajino, M., W. Winiwarter, and H. Ueda, 2006: Modeling retained water concent in measured aerosol mass. Atmos. Environ., 40, 5202-5213.

Kan, H., and B. Chen, 2004: Particulate air pollution in urban areas of Shanghai, China: health-based economic assessment. Sci. Total Environ., 322, 71-79.

Kim, D., and W. R. Stockwell, 2007: An online coupled meteorological and air quality modeling study of the effect of complex terrain on the regional transport and transformation of air pollutants over the Western United States. Atmos. Environ., 41, 2319-2334.

Liao, J., T. Wang, Z. Jiang, B. Zhuang, M. Xie, C. Yin, X. Wang, J. Zhu, Y.
Fu, and Y. Zhang, 2015: WRF/Chem modeling of the impacts of urban expansion on regional climate and air pollutants in Yangtze Delta, China. Atmos. Environ., 106, 204-214.

Marinoni, A., and Coauthors, 2010: Aerosol mass and black carbon concentration, a two year record at NCO-P (5079 m, Southern Himalayas). Atmos. Chem. Phy., 10, 8551-8562.

Martilli, A., and D. G. Steyn, 2004: A Numerical Study of Recirculation Processes in the Lower Fraser Valley (British Columbia, Canada). Air Pollution Modelling and Its Application XVII, Banff, 727 pp.

Miao, Y., S. Liu, Y. Zheng, S. Wang, and B. Chen, 2015: Numerical study of the effects of topography and urbanization on the local atmospheric circulations over the Beijing-Tianjin-Hebei, China. Adv. Meteorol., 2015, http://dx.doi.org/10.1155/2015/397070.

Min, H., J. Jing, and W. Zhijun, 2005: Chemical compositions of precipitation and scavenging of particles in Beijing. Sci. China Ser. B., $\mathbf{4 8}$, 265-272.

Nakajima, C., 1976: Movement and development of the clouds over Khumbu Himal in winter. Seppyo, 38, 89-92.

Panday, A. K., 2006: The Diurnal Cycle of Air Pollution in the Kathmandu Valley, Nepal. Ph.D. Thesis, Center for Global Change Science, Massachusetts Institute of Technology, $234 \mathrm{pp}$. and R. G. Prinn, 2009: Diurnal cycle of air pollution in the Kathmandu Valley, Nepal: Observations. J. Geophys. Res., 114. , R. G. Prinn, and C. Schar, 2009: Diurnal cycle of air pollution in the Kathmandu Valley, Nepal: 2. Modeling results. J. Geophys. Res., 114.

Putero, D., and Coauthors, 2015: Seasonal variation of ozone and black carbon observed at Pakanjol, an urban site in the Kathmandu Valley, Nepal. Atmos. Chem. Phy. Discuss., 15, 22527-22566.

Radke, L. F., P. V. Hobbs, and M. W. Eltgroth, 1980: Scavenging of Aerosol particles by precipitation. J. Appl. Meteor, 19, 715-722.

Regmi, R. P., T. Kitada, and G. Kurata, 2002: Numerical Simulation of Late Wintertime Local Flows in Kathmandu Valley, Nepal: Implication for Air Pollution Transport. J. Appl. Meteor., 42, 389-403.

Reid, J. D., 1978: Studies of pollutant transport and turbulent dispersion over rugged Mountainous terrain near Climax, Colorado. Atmos. Env. 13, 23-28.

Saha, A., and K. K. Moorthy, 2004: Impact of Precipitation on Aerosol Spectral Optical Depth and Retrieved Size Distributions: A Case Study. J. Appl. Meteor, 43, 902-914.

Segal, M., C.-H. Yu, and R. A. Pielke, 1988: Model Evaluation of the Impact of Thermally Induced Valley Circulation in the Lake Powell Area on Long-Range Pollutant Transport. JAPCA, 38, 163-170.

Sellegri, K., P. Laj, H. Venzac, J. Boulon, D. Picard, P. Villani, P. Bonasoni, A. Marinoni, P. Cristofanelli, and E. Vuillermmoz, 2010: Seasonal variations of aerosol size distributions based on long-term measurements at the high altitude Himalayan site of Nepal Climate Observatory-Pyramid (5,079 m), Nepal. Atmos. Chem. Phy., 10, 6537-6566.

Shrestha, A. B., C. P. Wake, P. A. Mayewski, and J. E. Dibb, 1999: Maximum Temperature Trends in the Himalaya and Its Vicinity: An Analysis Based on Temperature Records from Nepal for the Period 1971-94. J. Climate, 12, 2775-2786.

J. E. Dibb, P. A. Mayewski, S. I. Whitlow, G. R. Carmichael, and M. Ferm, 2000: Seasonal variations in aerosol concentrations and compositions in the Nepal Himalaya. Atmos. Environ., 34, 3349 .

and S. I. Whitlow, 2002: Aerosol and Precipitation Chemistry at a Remote Himalayan Site in Nepal. Aerosol Sci. Technol., 36, 441-456.

Shrestha, M. L., 2000: Interannual variation of summer monsoon rainfall over Nepal and its relation to Southern Oscillation Index. Meteorol. Atmos. Phys., 75, 21-28.

Shrestha, P., and A. P. Barros, 2010: Joint spatial variability of aerosol, 
clouds and rainfall in the Himalayas from satellite data. Atmos. Chem Phy., 10, 8305-8317.

and A. Khlystov, 2010: Chemical composition and aerosol size distribution of the middle mountain range in the Nepal Himalayas during the 2009 pre-monsoon season. Atmos. Chem. Phy., 10, 11605-11621.

Thapa, R. B., and Y. Murayama, 2011: Urban growth modeling of
Kathmandu metropolitan region, Nepal. Comput. Environ. Urban Syst., 35, 25-34.

Venzac, H., and Coauthors, 2008: High frequency new particle formation in the Himalayas. Proc. Natl. Acad. Sci., 105, 15666-15671.

Whiteman, C. D., 2000: Mountain Meteorology. Oxford University Press, $355 \mathrm{pp}$. 